\title{
The reproduction of Blennius pavo (Teleostei, Blenniidae). \\ I. Ovarial cycle, environmental factors and feeding
}

\author{
Robert A. Patzner \\ Zoological Institute, University of Salzburg; Akademiestr. 26, \\ A-5020 Salzburg, Austria \\ and \\ Marine Biological Laboratory of "Sorgenti di Aurisina"; I-Trieste, Italy
}

\begin{abstract}
Blennius (Salaria) pavo is a very common coastal fish in the Mediterranean Sea. The development of the ovary was studied over a period of one year; seven stages of oogenesis are described. Ripe eggs are carried during the spawning season from Juni to August. The ovary shows a resting period of more than half a year (September to March). Environmental factors of the study area such as surface water temperature and daylength are described as well as the condition factors of male and female fish. Observations on food and behaviour during the winter months are also included.
\end{abstract}

\section{INTRODUCTION}

The Northern Adriatic Sea is a very shallow part of the Mediterranean. The shallowness causes relatively low water temperature during winter time. The tidal difference can exceed $100 \mathrm{~cm}$ (Stravisi et al., 1981). Salinity is about $37 \%$; however heavy rain, swelling the brooks which enter the Northern Adriatic Sea, may cause a rapid decrease of the salinity of surface water.

Blennius pavo is a very common fish species in the littoral areas of the Mediterranean Sea (Fishelson, 1963; Patzner, in preparation). Until now gonadal cycles of blenniid fish have been described for two Atlantic species only, Blennius pholis (Shackley \& King, 1977a; Dunne, 1977) and B. galerita (Fives, 1980). Previous laboratory experiments have confirmed that water temperature and daylength are the controlling factors of gonadal ripening in $B$. pavo (Papitsch et al., 1982). Only very few observations exist on $B$. pavo during the winter (Kotrschal, 1982) and nothing is known about the feeding ecology for this time of the year.

This paper is the first of a series which deal with the reproduction of $B$. pavo.

\section{MATERIAL AND METHODS}

About every four weeks from April 1981 to June 1982 and every six weeks during winter time, female Blennius pavo were caught in the harbour of the Marine Biological 


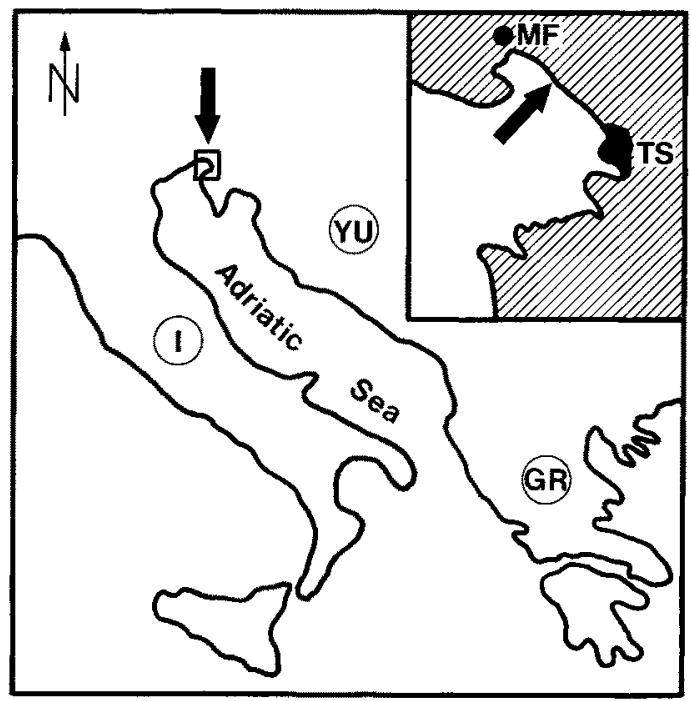

Fig. 1. Map of the study area. Arrow in insert indicates the Marine Biological Station of Aurisina, situated between Trieste (TS) and Monfalcone (MF)

Station of Aurisina (University of Trieste), situated between Trieste and Monfalcone (Fig. 1). The harbour is quite small $(20 \times 60 \mathrm{~m})$ and not seriously polluted. In its stone walls there are many clefts and holes. The animals are found from the water line down to about $1 \mathrm{~m}$ below the mid-water line. Males stay in their cavities even if the entrance to the hole becomes dry during low water. At extremely low tides several female and juvenile $B$. pavo were found below stones without any water.

The animals were captured in plexi-glass traps baited with crushed Mytilus. During the winter time when it was not possible to catch the fish in traps, Quinaldine (Fluka) diluted in Acetone 1:10 was used to anaesthetize the animals slightly and catch them by hand nets.

After anaesthetizing them with $0.2 \%$ MS 222 (Sandoz) in sea water the fish were measured to the nearest millimeter (total and standard length) and weighed to the nearest $0.01 \mathrm{~g}$. The condition factor was calculated as body weight $\times 100$ $\times$ standard length ${ }^{-3}$. The peritoneal cavity was opened and the total animal fixed in Bouin's fluid. After removing the intestine, the genital papilla and the ovary, the latter was weighed to the nearest $0.0001 \mathrm{~g}$ to calculate the $\mathrm{g}$ on a dos om at i c in dex $\left(\right.$ GSI $=$ gonad weight $\times 100 \times$ body weight $\left.{ }^{-1}\right)$. After dehydration in alcohol and embedding in paraffin, $7 \mu \mathrm{m}$ thick cross sections of the genital papilla were stained with haematoxylin and eosin (H. E.) or Azan (Heidenhain).

The intestinal contents of the animals caught in winter were studied under a dissecting and a light microscope. Thereby, the contents of the whole intestine were examined. The percentage composition was analyzed by the point and the occurrence method (Hynes, 1950).

The age of large animals was determined by examining the sagittal otoliths. They were removed before fixation of the animals and brought over absolute ethanol into winter green oil to make them transparent. 


\section{RESULTS}

\section{Habitat and animals}

A diagram showing the day length in the region of Trieste and the water temperature during the year when the observations were made is given in Figure 2. From January to the middle of March when the water temperature was below $10^{\circ} \mathrm{C}$, most Blennius pavo stayed in holes or clefts. Sometimes single females were seen outside the holes among the algae. At that time of the year it was not possible to catch any Blennius individuals by baited traps.

The length/weight relationship or condition factor (CF) shows two peaks within the annual cycle (Fig. 3). The first one is at the start of the spawning season at the beginning of June. After that the CF decreases until the middle of September. The next peak occurs in October. From there on, during the winter months until March, a permanent decrease

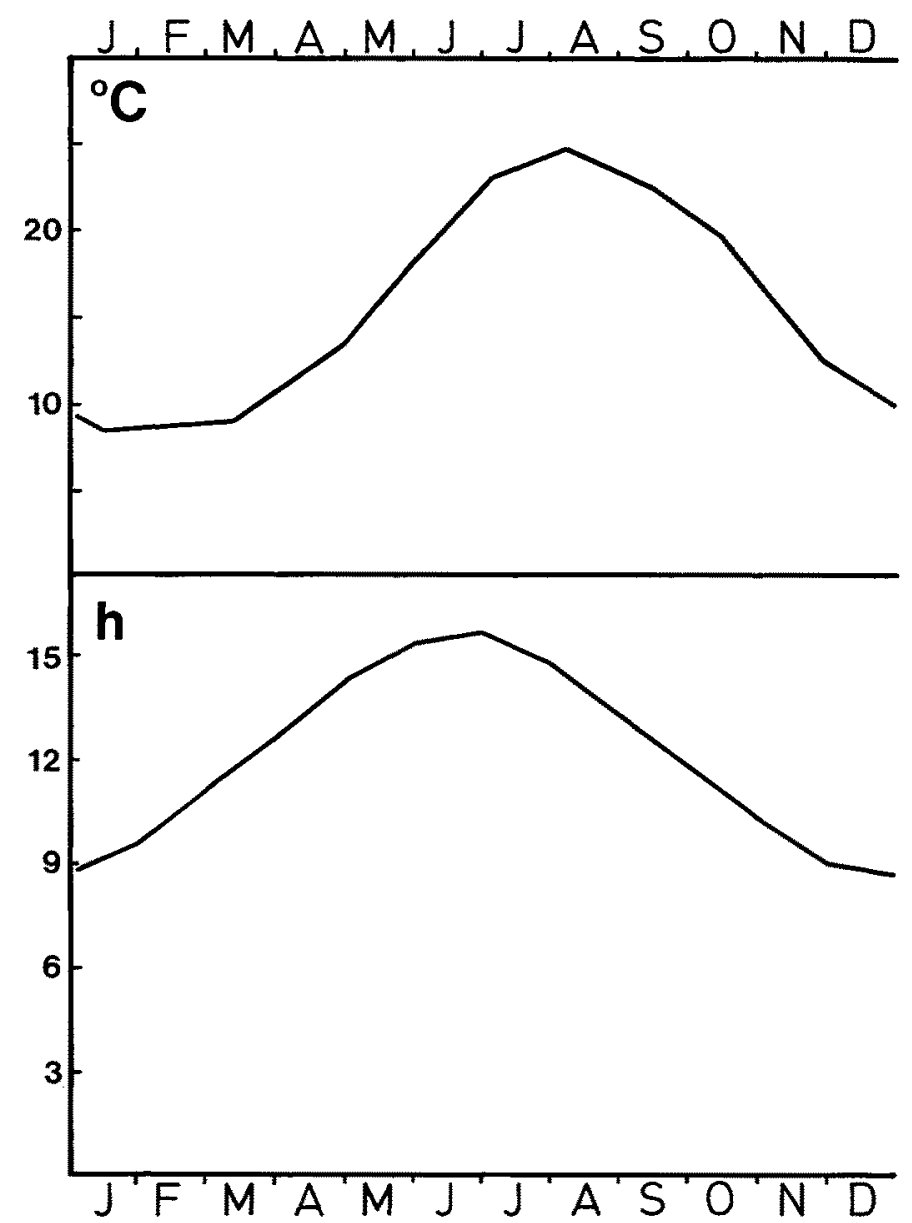

Fig. 2. Surface water temperature $\left({ }^{\circ} \mathrm{C}\right)$ at Aurisina in the studied year, and daylength $(\mathrm{h})$ in the region of Trieste. Data of the daylength from Amiran \& Schick (1961) 


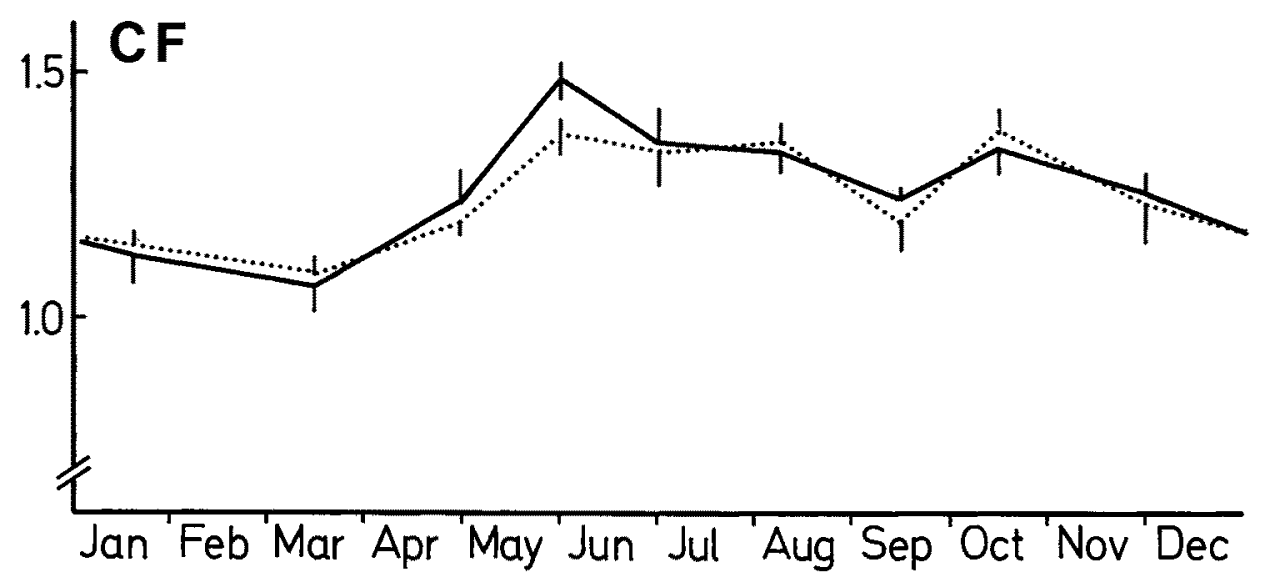

Fig. 3. Condition factors (CF) of male (continuous line) and female (dotted line) Blennius pavo in the course of one year (observation period: 1981-1982). Vertical bars represent standard errors
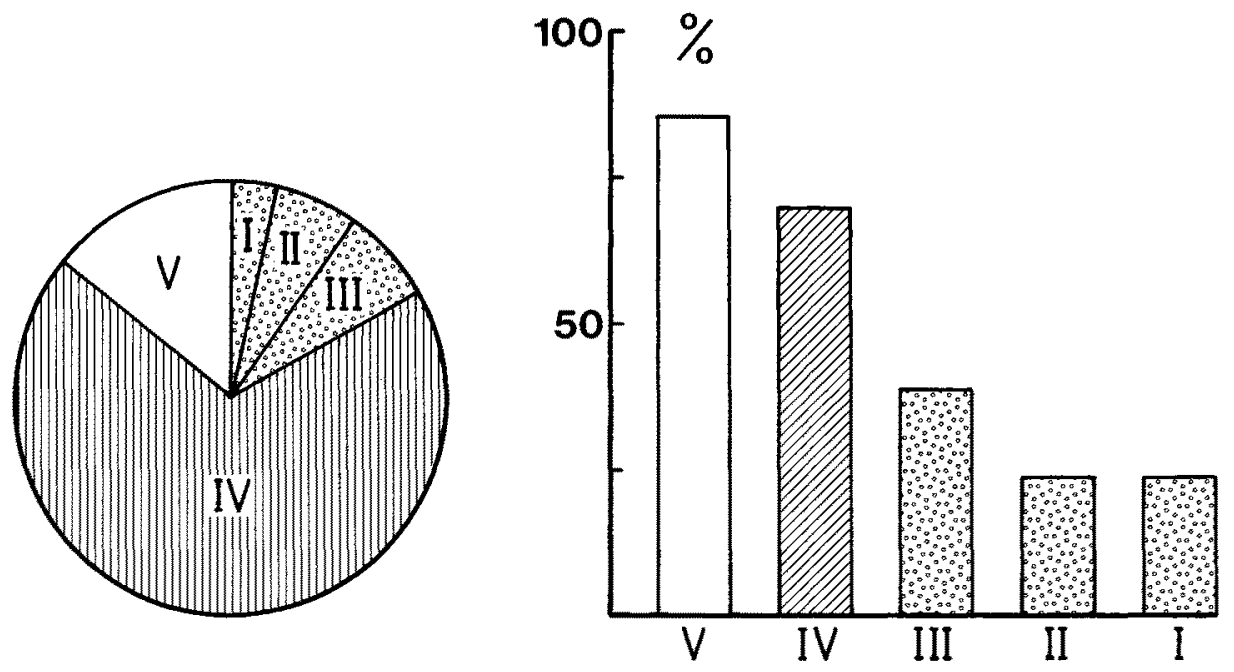

Fig. 4. Composition of the winter diet in Blennius pavo after the point method (left) and the occurrence method (right) respectively. I = sedentary fauna, II = large vagile fauna, III = small vagile fauna, $\mathrm{IV}=$ algae, $\mathrm{V}=$ detritus

can be observed. At that time the CF reaches its lowest point in the year. From March on there is a strong increase lasting until the spawning season.

The largest male $B$. pavo caught had a total length of $140 \mathrm{~mm}$, a standard length of $124 \mathrm{~mm}$ and a weight of $23.47 \mathrm{~g}$. The largest female had a total length of $131 \mathrm{~mm}$, a standard length of $114 \mathrm{~mm}$ and a weight of $20.81 \mathrm{~g}$. Both animals were caught in May, 1981 and were 8 years of age.

Investigations of the gut contents of 19 animals caught in winter showed that 8 animals $(42 \%)$ had a completely empty intestine. In only one fish was the gut more than half filled the rest contained only a few items. In total only $12 \%$ of the intestine was 
filled. The results of the point and the occurrence method are shown in Figure 4 . The point method is an estimated volumetric method and the occurrence method shows the occurrence of food items in the gut.

\section{Ovary}

The development of the oocytes in the ovary of Blennius pavo can be divided into seven stages:

Stage I: Smaller than $30 \mu \mathrm{m}$. Oogonia. Mostly singular and sometimes in small groups in the germinal epithelium surrounding accumulations of developing oocytes. No nucleoli are visible within the nucleus. The nucleus is large compared with the size of the cell. The cytoplasm appears dark in H. E. stained sections (Fig. 7a, b, c, d). Oogonia are found in the ovary throughout the whole year (Fig. 5), Stage I corresponds to Stage 1 from Shackley \& King $(1977 b)$ in Blennius pholis.

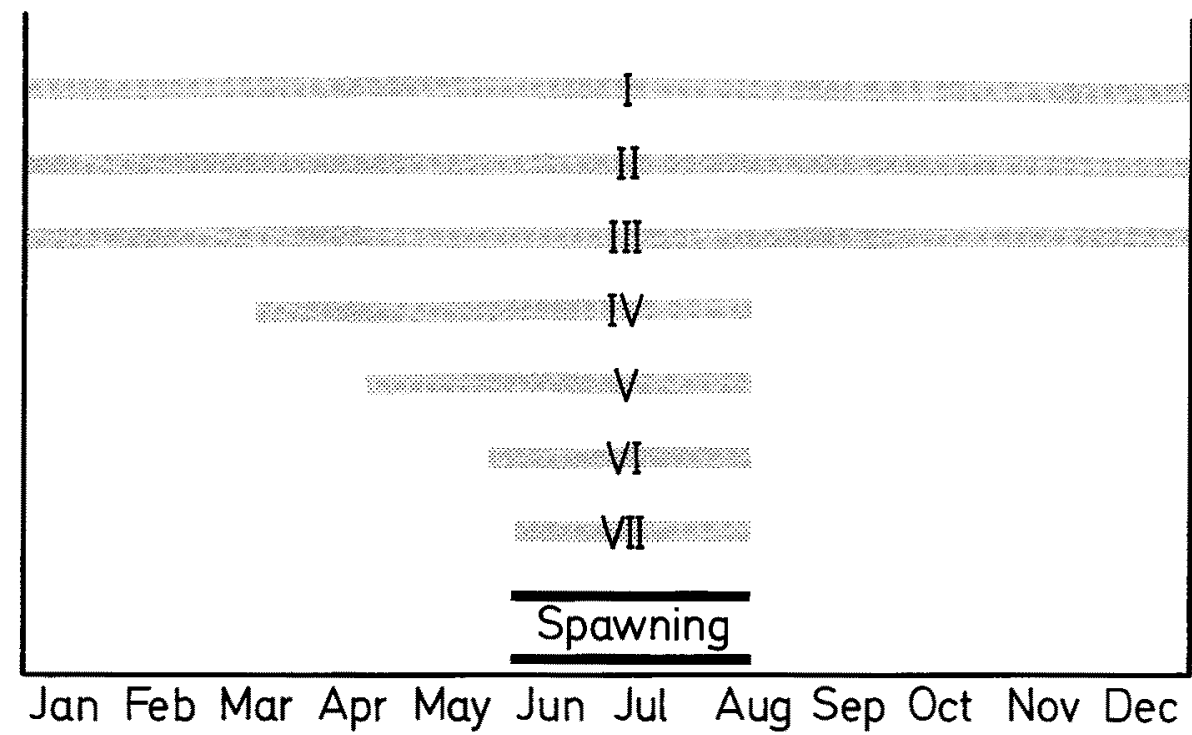

Fig. 5. Distribution of oocytes (Stage I to Stage VII) in the ovary of Blennius pavo in the course of one year

S ta ge II : Diameter up to roughly $100 \mu \mathrm{m}$. The oocytes are already surrounded by a thin layer of follicular epithelium. The round bubble-shaped nucleus is situated in the middle of the cell. In stained sections the cytoplasm appears as dark as in Stage I (Fig. 7a, b, c, d, f). Stage II oocytes are present throughout the year (Fig. 5) and correspond to early Stage 2 from Shackley \& King $(1977 b)$.

S t a ge I I I : Diameter up to about $140 \mu \mathrm{m}$. In H. E. stained material they can easily be distinguished from oocytes of Stage II: the cytoplasm appears much lighter. No structure in the cytoplasm is visible. The nucleus lies in the middle of the cell, with several nucleoli at the outer margin. At one pole of the oocyte the adherent disc with the later filaments begins to develope (Fig. $7 \mathrm{a}, \mathrm{b}, \mathrm{c}$, d). Stage III oocytes are present throughout the whole of the reproductive cycle (Fig. 5) and correspond to late Stage 2 and early Stage 3 from Shackley \& King (1977b). 


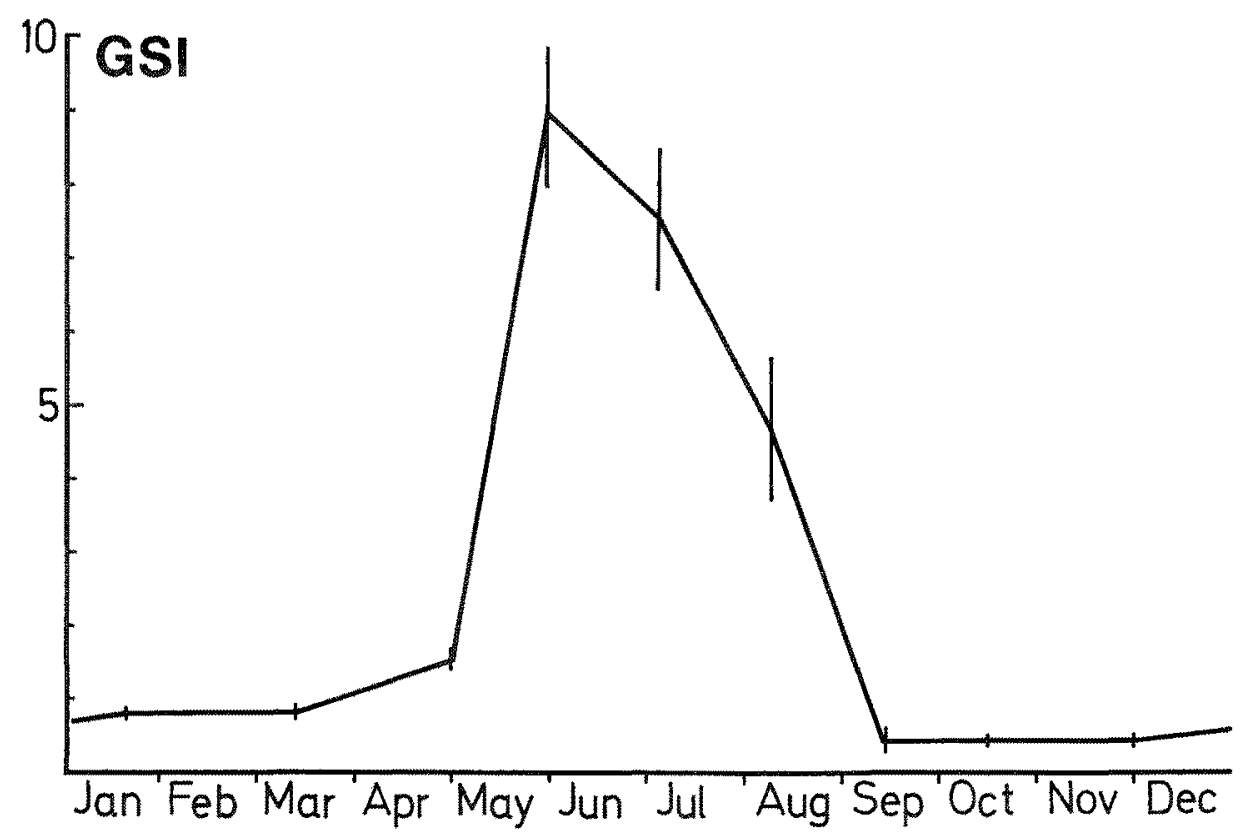

Fig. 6. Gonadosomatic indices (GSI) of female Blennius pavo in the course of one year. Vertical bars represent standard errors

Stage IV: Oocytes with a diameter up to $230 \mu \mathrm{m}$. They are only present in the ovary from March to August. (Fig. 5). A few vacuoles (= cortical alveoli, "Rindenvakuolen" see Arndt, 1960) can be seen within the cytoplasm. The pole with the adherent disc can already be well distinguished (Fig. $7 \mathrm{c}$ ). The cytoplasm appears light. Stage IV oocytes correspond to late Stage 3 from Shackley \& King (1977b).

$\mathrm{Stage} \mathrm{V}$ : Oocytes with a diameter up to about $400 \mu \mathrm{m}$. They are present in the ovary from April to August (Fig. 5). The cytoplasm is nearly filled with cortical alveoli. The round nucleus is situated more or less in the middle of the cell. The nucleoli are not only at the outer margin but are spread all over the nucleus. The adherent disc is 35 to $40 \mu \mathrm{m}$ thick (Fig. $7 \mathrm{~d}, \mathrm{f}$ ). Stage $\mathrm{V}$ oocytes correspond to late Stage 4 and Stage 5 from Shackley \& King (1977b).

Stage VI: Oocytes with a diameter up to about $800 \mu \mathrm{m}$. This stage is found in the ovary from late May to August (Fig. 5). The cytoplasm is completely filled with yolk granules. The nucleus is situated in the middle of the cell and contains various nucleoli. The nucleoli are more or less concentrated in the middle of the nucleus, leaving the outer margin free. The adherent disc is about $40 \mu \mathrm{m}$ thick (Fig. 7f). Stage VI oocytes correspond to Stage 7 and Stage 8 from Shackley \& King (1977b).

Stage VII: Ripe eggs with a diameter af about $1200 \mu \mathrm{m}$. They are present in the ovary only during the spawning season from June to August (Fig. 5). The cytoplasm is completely filled with large yolk platelets (Fig. $7 \mathrm{e}, \mathrm{f}$ ). The nucleus appears very light in H.E. stained sections. No nucleoli were observed within the nucleus. A detailed description of the ripe egg will be given (Patzner, in preparation).

In September, after the end of the spawning season, the GSI of the female B, pavo 

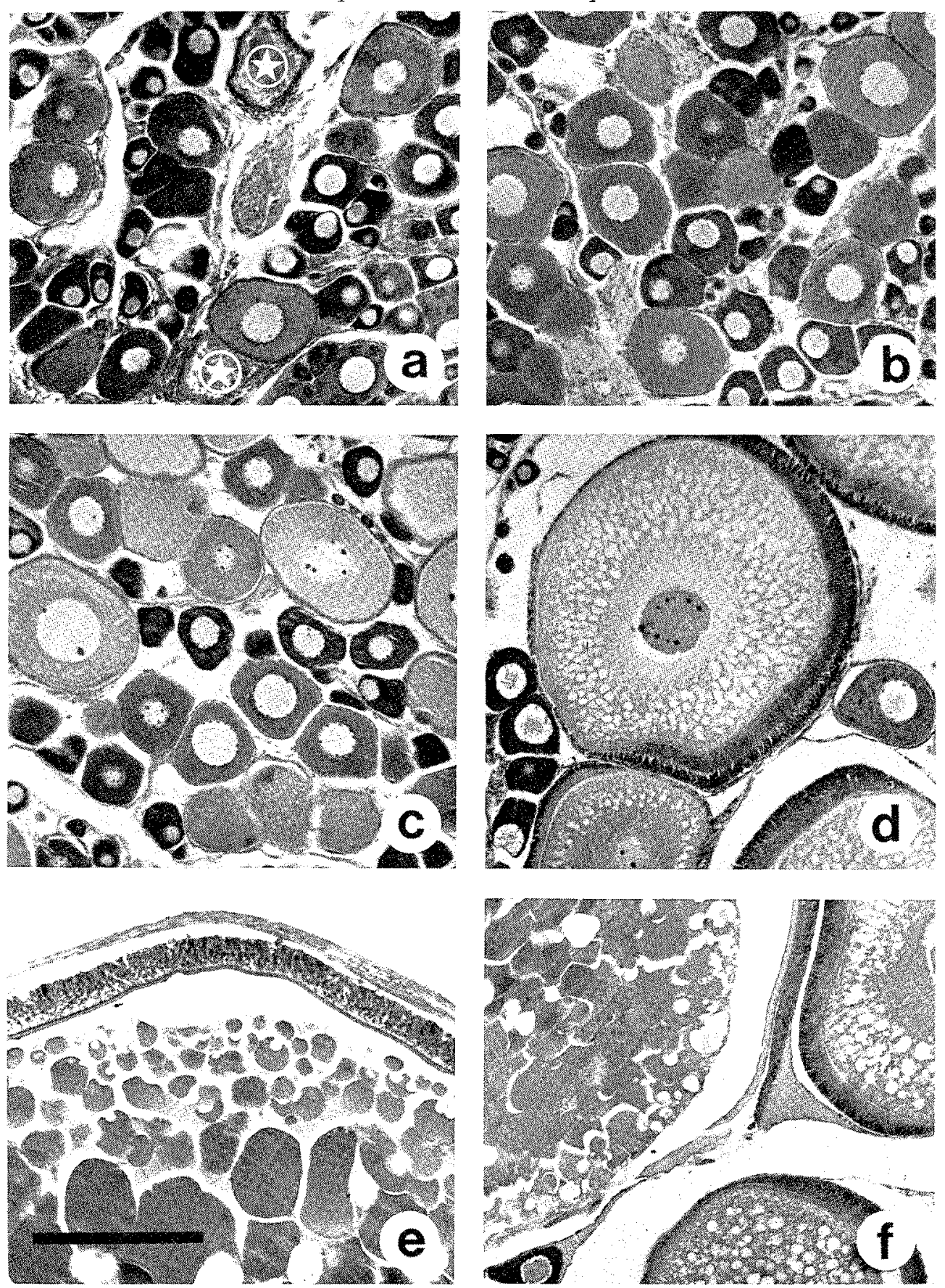

Fig. 7. Sections of ovaries of Blennius pavo (scale: $200 \mu \mathrm{m}$ ). For description of stages of oocytes see text. (a) September, Stages I to III, atretic follicles (asterisks). (b) December, Stages I to III. (c) March, Stages I to IV. (d) Early May, Stages I to III, and V; note adherent disc in Stage V. (e) June, ripe eggs, yolk platelets and adherent disc. (f) June, Stages II, V, VI, VII 
reaches its minimum with $0.44 \pm 0.11$ (mean \pm standard error) (Fig. 6). In the ovary one can find several muptured and atretic follicles as well as oogonia and oocytes of Stage II and Stage III (Fig. 7a). The only change within the next month is that in October no more ruptured and no more atretic follicles are found in the ovary. The GSI is nearly the same $(0.53 \pm 0.04)$. During the winter, from November to February, no changes in the ovary can be observed (Fig. $7 \mathrm{~b}$ ). The GSI increases very slightly to $0.79 \pm 0.06$ at the end of January (Fig. 6).

In the middle of March the GSI is at $0.79 \pm 0.16$ still the same as two months before (Fig. 6) but the oocytes have already started their further growth. At that time of the year, when the water temperature is still below $10^{\circ} \mathrm{C}$, the oocytes have reached Stage IV (Fig. 7c). At the end of April and the beginning of May, when the water temperature is already above $13{ }^{\circ} \mathrm{C}$, the GSI has increased to twice its value, i. e. to $1.61 \pm 0.15$. Histological sections of the ovary show all oocyte stages from I to V (Figs 5, 7d). During May there is an enormous increase of the GSI of the female B. pavo. With the beginning of Juni, when the water temperature is higher than $18^{\circ} \mathrm{C}$, the GSI reaches its maximum with $8.99 \pm 1.08$ (Fig. 6). At that time the ovary is nearly filled with oocytes of Stage VI and Stage VII (Fig. 7e, f). The rest is filled with Stages I to V and already ovulated follicles, indicating that the first spawning has already taken place.

The spawning season of $B$. pavo lasts from the beginning of June to about the middle of August. During that time a regular decrease of the GSI of the ovary, caused by the repeated spawning of females, can be observed. The ruptured follicle left after discharge of the ripe egg obviously does not form a corpus luteum. It shrinks rather quickly and disappears. No histological changes can be seen within the ovary during the spawning season. There is no visible increase in the number of ovulated follicles. All stages of oocytes can still be observed in the middle of August.

No histological changes were found in the region of the genital papilla and the genital pore of female $B$. pavo throughout the reproductive cycle.

\section{DISCUSSION}

Investigations of the ovary of Blennius pavo showed a regular annual reproductive cycle. As the light-dark period and water temperature are the controlling factors of the gonadal ripening (Papitsch et al., 1982), special attention was given to these circumstances in the study area of the Northern Adriatic Sea. The period before spawning is characterized by an increase of both water temperature and day length (Fig. 2).

B. pavo is a true euryhaline species which can live in salinities down to $22 \% \mathrm{~S}$ (Gibson, 1969; Zander, 1972). There is no reason to assume that slight changes of salinity could influence the reproductive cycle of these fish, because heavy rainfall can occur in the study area all through the year. Therefore no special consideration was given to this question.

The condition factor $(\mathrm{CF})$ reaches its first maximum at the beginning of the spawning season, especially in males. Male B. pavo take parental care of the eggs and usually stay in their cavities during the whole of the spawning season (Eggert, 1932; Fishelson, 1963; Wirtz, 1977), whereas the females move around freely. Therefore, the males do not have much opportunity to obtain food during spawning and have to gain weight before that. After spawning, the decrease of the CF lasts only for a short time. The fish then feed 
a lot to get through the relatively cold winter season, when they move and feed only little. B. pavo, kept in aquaria at a water temperature of $8^{\circ} \mathrm{C}$, hardly took any food (Patzner \& Papitsch, unpublished observation).

The results of the studies of the gut content correlate very well with those of the condition factor. It is shown that winter animals take very little food. A comparison with $B$. pavo, studied in late spring and in summer showed quite a different content the gut (Gibson, 1968; Kotrschal \& Goldschmid, 1982). The latter authors found the following contents of the intestines of $10 \mathrm{~B}$. pavo by the point method: algae $12 \%(69 \%)$, sedentary fauna $1 \%(3 \%)$, large vagile fauna $60 \%(6 \%)$, small vagile fauna $2 \%(7 \%)$, and detritus $26 \%(14 \%)$. The numbers in parenthesis show my own results from the winter animals in the present paper. The main food in winter consists of algae, in summer of large vagile fauna like crustaceans and polychaetes.

The ovary of $B$. pavo shows a considerably long resting phase compared to other fish (Barr, 1963; Braekevelt \& McMillan, 1967; Hoar, 1969, and others) and even compared to other blennies, B. pholis (Shackley \& King, 1977a; Dunne, 1977) and B. galerita (Fives, 1980), both from the Atlantic. Gonadal cycles of Mediterranean species of Blennius have not been investigated so far. Only few fishes are known to have such a long ovarial resting phase (e.g. Kuo \& Nash, 1979).

The oogenesis of B. pavo is similar to that of other teleost fishes (Bara, 1960; Götting, 1961; Barr, 1963; Shackley \& King, 1977b, and others). The present investigation shows that in September, when the spawning season is over, several atretic follicles were found in the ovary. This observation demonstrates that eggs which are not spawned are absorbed rapidly.

Fishelson (1963) describes the urogenital papilla of $B$. pavo during the breeding season as conspicuously red. This, however, could neither be observed in nature, nor in the aquarium (Patzner \& Papitsch, in preparation). No histological changes, such as an increase of blood vessels, could be found.

Acknowledgements. This study was supported by the "Stiftungs- und Förderungsgesellschaft der Paris Lodron-Universität in Salzburg" and the Austrian "Fonds zur Förderung der wissenschaftlichen Forschung" (Grant No. 4070). The author is grateful to the director of the Marine Biological Station of Aurisina (University of Trieste), Dr. M. Specchi for providing working facilities, Mag. M. Papitsch and Mag. A. Galabov for technical assistance, Dr. K. Kotrschal for help in determining the gut contents, and Prof. H. Adam for his encouragement. Thanks are also due to "Viking Comp." (Norway) for providing a diving-suit.

\section{LITERATURE CITED}

Amiran, D. H. \& Schick, P., 1961. Geographical conversion zones. Aschmann \& Scheler, Zürich, $310 \mathrm{pp}$.

Arndt, E. A., 1960. Über die Rindenvakuolen der Teleosteer-oocyten. - Z. Zellforsch. mikrosk. Anat. $51,209-224$.

Bara, G., 1960. Histological and cytological changes in the ovaries of the mackerel "Scomber scomber L.", during the annual cycle. - Revue Fac. Sci., Univ. Istambul (B) 25, 49-91.

Barr, W. A., 1963. The endocrine control of the sexual cycle in the plaice, Pleuronectes platessa (L). I. Cyclical change in the normal ovary. - Gen. comp. Endocrinol. 3, 197-204.

Braekevelt, C. R. \& McMillan, D. B., 1967. Cyclical changes in the ovary of the brook stickleback Eucalia inconstans (Kirtland). - J. Morph. 123, 373-396.

Dunne, J., 1977. Littoral and benthic investigations on the west coast of Ireland - VII. (Section A: 
faunistic and ecological studies). The biology of the shanny, Blennius pholis L. (Pisces) at Carna, Connemara. - Proc. R. Ir. Acad. 77, 207-226.

Eggert, B., 1932. Zur Kenntnis der Biologie, der sekundären Geschlechtsmerkmale und des Eies von Blennius pavo Risso. - Z. Morph. Okol. Tiere 24,682-703.

Fishelson, L., 1963. Observation on littoral fishes of Israel. I. Behaviour of Blennius pavo Risso (Teleostei, Blenniida). - Israel J. Zool. 12, 67-80.

Fives, J. M., 1980. Littoral and benthic investigations on the west coast of Ireland - XI. The biology of Montagu's Blenny, Coryphoblennius galerita L. (Pisces), on the Connemara coast. - Proc. R. Ir. Acad. 80, 61-77.

Gibson, R. N., 1968. The food and feeding relationships of littoral fish in the Banyuls region. - Vie Milieu (A) $19,447-456$.

Gibson, R. N., 1969. The biology and behaviour of littoral fish. - Oceanogr. mar. Biol. 7, 367-410.

Götting, K.-J., 1961. Beiträge zur Kenntnis der Grundlagen der Fortpflanzung und zur Fruchtbarkeitsbestimmung bei marinen Teleosteern. - Helgoländer wiss. Meeresunters. 8, 1-41.

Hoar, W. S., 1969. Reproduction. In: Fish physiology. Ed. by W. S. Hoar \& D. J. Randall. Acad. Press, New York, 3, 1-72.

Hynes, H. B. N., 1950. The food of fresh-water sticklebacks (Gasterosteus aculeatus and Pygosteus pungitius), with a review of methods used in studies of the food of fishes. - J. Anim. Ecol. 19, $36-58$.

Kotrschal, K., 1982. Behaviour ecology of Northern Adriatic littoral rocky reef fishes at low winter temperature; the possible meaning of permanent environmental temperature changes to exothermic, sympatric and resident organisms, - P.S.Z.N. I: Mar. Ecol. (in press).

Kotrschal, K. \& Goldschmid, A., 1982. Food preferences, morphology and arrangement of teeth of 14 species of Adriatic blennies (Pisces, Teleostei). - Thalassia jugosl. 17 (in press).

Kuo, C.-M. \& Nash, C. E., 1979. Annual reproductive cycle of milkfish, Chanos chanos Forskal, in Hawaiian waters. - Aquaculture 16, 247-251.

Papitsch, M., Patzner, R. A. \& Adam, H., 1982. Effects of photoperiod and temperature on gonadal maturation of Blennius (=Salaria) pavo (Teleostei, Blennniidae). - Vie Milieu (in press).

Shackley, S. E. \& King, P. E., 1977a. The reproductive cycle and its control; frequency of spawning and fecundity in Blennius pholis L. - J. exp. mar. Biol. Ecol. 30, 73-83.

Shackley, S. E. \& King, P. E., 1977 b. Oogenesis in a marine teleost, Blennius pholis L. - Cell Tiss. Res. 181, 105-128,

Stravisi, F., Ferraro, S. \& Luca, I., 1981. Golfo di Trieste previsioni di marea per il 1982. - Nova Thalassia 5 (Suppl. 1), 1-32.

Wirtz, P., 1977. Zum Verhalten blennioider Fische, insbesondere der mediterranen Trypterygion Arten. - Diss., Univ. München, 78 pp.

Zander, C. D., 1972. Beiträge zur Ökologie und Biologie von Blenniidae (Pisces) des Mittelmeeres. Helgoländer wiss. Meeresunters. 23, 193-231. 